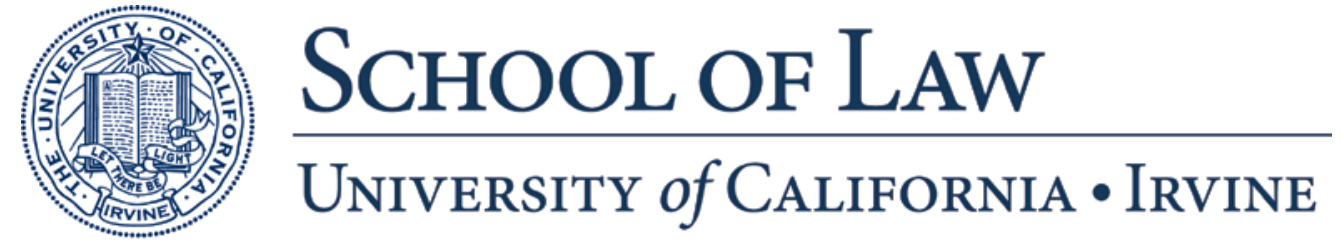

Legal Studies Research Paper Series No. 2014-28

\title{
Means and Meaning in Patent Remedies
}

\author{
Dan L. Burk \\ dburk@law.uci.edu \\ University of California, Irvine School of Law
}




\section{Texas Law Review}

\section{See Also}

Volume 92

\section{Response}

\section{Means and Meaning in Patent Remedies}

\section{Dan L. Burk*}

\section{Introduction}

In his article, Purging Patent Law of "Private Law" Remedies, Professor Sichelman offers a welcome and useful perspective on the reform of patent remedies. His general thesis - that patent law's policy of promoting innovation must take precedence in shaping the outcome of patent cases - is surely correct, and his goal of ensconcing innovation as the guiding principle of patent remedies is admirable.

Yet as a teacher of torts and remedies as well as patents, I worry as I trace the road he takes toward that goal. My concern is that he may be blazing a trail that is far steeper and rougher than it need be. I suspect first, that he has made some unnecessary assumptions about the nature of the remedial enterprise; and second, that his recommendation to "purge patent law," with its undertones of ethnic cleansing or medieval medical treatment, is probably needlessly dramatic. Many of the doctrinal tools that could effect his preferred changes are already well-known among scholars of remedies, property, and tort - in short, amid precisely the "private" legal regimes he says he fears.

In my discussion of these matters below, I first take up the point regarding terminology and characterization, suggesting that the language of "making whole" to which Sichelman objects might in fact mean precisely what Sichelman wants patent remedies to mean. I then turn to sketching several examples of existing and underutilized tools that might accomplish much of Professor Sichelman's agenda without necessarily fomenting a radical reconceptualization of patent-remedies doctrine. Along the way I suggest how such implementation might play out in a variety of current

* Chancellor's Professor of Law, University of California, Irvine. 
patent controversies, including Sichelman's example of patent "trolls," as well as FRAND licensing and pharmaceutical "pay for delay" agreements.

\section{Finding New Meaning}

Sichelman argues that patent law's policy of innovation promotion suffers from being characterized as a form of tort, that is, being characterized as a system of private rights and wrongs. ${ }^{1}$ One is immediately tempted to at least quibble with this characterization of patent-as-tort in terms of public and private wrongs. It is not at all clear that his characterization of tort remedies as addressing "private" wrongs is meaningful. Since at least the publication of Calabresi's The Costs of Accidents, ${ }^{2}$ if not before, the American discourse on torts has been largely couched in terms of public welfare. $^{3}$ Tort law is now generally seen as a complement or an alternative to other public systems such as nationalized health insurance or worker's compensation. ${ }^{4}$ Tort damages are routinely discussed and calibrated in terms of internalizing the costs of social activity, optimizing safety precautions, and distributing the losses that arise from socially beneficial enterprises. ${ }^{5}$

Neither is it clear that Sichelman's other points of comparison, such as property law, are remedially private in the sense that concerns him. ${ }^{6}$ Property law, the quintessential Anglo-American personal possessory privilege, is typically justified as a mechanism for harnessing private ordering to further the public interest. ${ }^{7}$ Indeed, patent law is generally lauded as a form of property - rather than, say, formulated a system of prizes or auctions ${ }^{8}$ - because it incorporates the assumption that rectifying private wrongs may be coterminous with optimizing public welfare-a notion that stems from the Demsetzian strain of property theory. ${ }^{9}$ This leaves contract

1. Ted Sichelman, Purging Patent Law of "Private Law" Remedies, 92 TEXAS L. REV. 517, 522 ("I argue in this Article, however, that the traditional view [treating the patentee like a private right-holder entitled to traditional private law remedies optimally promotes innovation] is wrong ....").

2. Guido CAlabresi, The Costs of ACCIDENTS: A Legal AND ECONOMiC ANALysis (1970).

3. See Richard A. Posner, Guido Calabresi's The Costs of Accidents: A Reassessment, 64 MD. L. REV. 12, 12 (2005) (tracing the changes in conceptions of torts effected by Calabresi's pioneering work).

4. See, e.g., Marc A. Franklin, Robert L. Rabin \& Michael D. Green, Tort Law And ALTERNATIVES (9th ed. 2011).

5. See, e.g., William M. LANDES \& Richard A. Posner, The ECONOMiC STRUCture of TORT LAW 58-59 (1987); RICHARD A. POSNER, ECONOMIC ANALYSIS OF LAW 163-65, 181 (4th ed. 1992) (hereinafter, POSNER, ECONOMIC ANALYSIS).

6. Sichelman, supra note 1 , at 518.

7. See, e.g., POSNER, ECONOMIC ANALYSIS, supra note 5, at 36.

8. See generally Daniel J. Hemel \& Lisa Larrimore Ouellette, Beyond the Patents-Prizes Debate, 92 TEXAS L. REV. 303 (2013) (discussing potential structuring of innovation incentives).

9. See Dan L. Burk, Law and Economics of Intellectual Property: In Search of First Principles, 8 ANN. REV. L. \& Soc. SCI. 397, 405 (2012) ("Property rights are thus believed to align public and private interests."); see also Harold Demsetz, Toward a Theory of Property Rights, 57 AM. ECON. 
law as perhaps the only major sector of common law jurisprudence Sichelman identifies that remains fundamentally private in its remedial orientation-although it is not at all difficult to find a public welfare justification for contractual remedies as well. ${ }^{10}$

The point here is that there is nothing especially private about most bodies of "private law" that Sichelman identifies for comparison, and there is certainly no particular need to purge torts or property of their private remedies in order to effectuate the public welfare goals of either. Nor is it clear that there is a need to purge patent law in order to effectuate its public welfare goals. Sichelman is likely right that courts are stuck in something of a rut when it comes to patent remedies - there are certain ossified underlying assumptions about what constitutes a harm, and how harms ought to be rectified. ${ }^{11}$ But such myopia likely has more to do with inertia or judicial overload than with any principled distinction between public welfare and private causes of action.

Sichelman worries that patent remedies intended to rectify private wrongs will tend to provide excessive rewards, or in certain specialized cases may provide insufficient rewards, if not calibrated to the particular industry to which the patent pertains. ${ }^{12}$ In previous work with Mark Lemley, I have argued that excessive rewards can be avoided, and the proper innovation incentive calibrated, by courts employing flexible statutory provisions that we term "policy levers."13 Such provisions, providing judges with a varied calibration toolkit, are scattered throughout the substantive weft of the patent statute, and include remedial policy levers. ${ }^{14}$

Sichelman is essentially focused, as were we, on the proper deployment of such remedial levers. In this regard, his characterization of patent or other remedies as restoring the status quo or "making whole" bears some careful scrutiny. Sichelman's use of this terminology suggests a surprisingly static view of its meaning, as if the terms designate one particular remedial measure. But the metric of "making whole," or as Douglas Laycock has cannily termed it, restoring the parties to the "rightful position," 15 is never fixed, and instead shifts with judicial purpose.

This is manifest as between the branches of private law Sichelman chooses for comparison to patent law; the hypothetical position in which the tort plaintiff was never harmed entails an entirely different set of suppositions than the hypothetical position in which the contract plaintiff

REV. 347, 347-50 (1967) (discussing coordination of private incentives and public welfare in rules governing physical property).

10. See, e.g., POSNER, ECONOMIC ANALYSIS, supra note 5, at 90-91.

11. Sichelman, supra note 1 , at 518-22.

12. Sichelman, supra note 1 , at 523-26.

13. See Dan L. Burk \& Mark A. Lemley, The Patent Crisis and How the Courts Can SOLVE IT 109 (2009).

14. Id. at $128-30$.

15. Douglas Laycock, Modern AMERICAN ReMedies 13 (4th ed. 2012). 
received the benefit of the bargain. The same observation holds equally true within branches of law. The rightful position of a plaintiff in either tort or contract is always shaped by policy and practicality. And as Professor Lee has shown in a related context, restoration of the status quo is an equally mercurial concept, based on the selective perception of history and on the imaginative re-creation of reality. ${ }^{16}$ The status quo is never a settled point in time, but rather a hypothetical supposition with parameters that fluctuate doctrinally, procedurally, and situationally.

The situation is no different in the patent context. Consider one of the most vexing current injunctive problems to face judges in patent cases: the enforcement of a standard-essential patent that has been promised to licensors on fair, reasonable, and non-discriminatory terms. Standard-setting organizations typically require disclosure of intellectual property interests by their members when technological standards are being adopted. ${ }^{17}$ Patent owners in such circumstances are typically required to reveal the presence of a patent, and agree that if their technology is adopted as the standard, they will make licenses available on fair, reasonable, and non-discriminatory (FRAND) terms. ${ }^{18}$

A number of disputes have arisen where a patent holder claims infringement of a patent that he had previously promised to license on FRAND terms. ${ }^{19}$ In such a case, is the "status quo" that is to be restored the point in time at which the patent holder was free to exercise his exclusive rights, that is, prior to promising FRAND licenses? Or is it the point in time after which the patent holder agreed not to exercise exclusivity, that is, after FRAND terms were promised?

This same type of subjunctive plasticity is found not only when determining injunctive relief, but is manifest in the damages options articulated within the patent statute: lost profits or a reasonable royalty ${ }^{20}$ either hypothetical profits that would have been made in the absence of infringement, or a hypothetical sum that would be paid by an imaginary licensee to a fictional patent holder. Since we cannot in fact turn back the

16. See Thomas R. Lee, Preliminary Injunctions and the Status Quo, 58 WASH. \& LEE L. REV. 109, 166 (2001).

17. Mark A. Lemley, Intellectual Property Rights and Standard-Setting Organizations, 90 CALIF. L. REV. 1889, 1904 (2002).

18. Anne Layne-Farrar et al., Pricing Patents for Licensing in Standard-Setting Organizations: Making Sense of FRAND Commitments, 74 ANTITRUST L.J. 671, 671-72 (2007); Joseph Scott Miller, Standard Setting, Patents, and Access Lock-In: RAND Licensing and the Theory of the Firm, 40 IND. L. REV. 351, 353 (2006).

19. See, e.g., Microsoft Corp. v. Motorola, Inc., 696 F.3d 872 (9th Cir. 2012); Broadcom Corp. v. Qualcomm, Inc., 501 F.3d 297 (3d Cir. 2007); Apple, Inc. v. Motorola Mobility, Inc., No. 11-cv178-bbc, 2012 WL 5416941 (W.D. Wis. Oct. 29, 2012); Apple, Inc. v. Samsung Elecs. Co., No. 11 CV-01846-LHK, 2012 WL 2571719 (N.D. Cal. June 30, 2012); Microsoft Corp. v. Motorola, Inc., 864 F. Supp. 2d 1023 (W.D. Wash. 2012); Apple, Inc. v. Motorola Inc., No. 1:11-cv-08540, 2012 WL 1959560 (N.D. Ill. May 22, 2012).

20. 35 U.S.C. $§ 284$ (2012). 
clock to a time before the infringement occurred, we attempt to reconfigure the present to the state that it might be in had events followed a different path. The question, however, remains as to what causal factors we suppose to have been altered or removed. Should we assume that the sales made by the infringer displaced sales that would have been made by the patent holder? Or should the supposition be that the world should be reconfigured as if a licensing bargain had been struck?

Should the effects of the infringement be entirely erased, placing the patent holder in an environment that has been scrubbed clean of the infringer's actions? That is a very tall order for any court to undertake. Any attempt to truly reconstruct a world without the effects of infringement would require enormously wide-ranging judicial authority, perhaps rescinding consumer possession of illicitly distributed devices, or revising the contours of the patent holder's lost market share. In no branch of law do we expect that any type of remedy is entirely adequate to unscramble the egg, so we pick and choose what outcomes seem most pertinent, and we always do so on some supposition about the purpose of the statute.

The question for patents, then, is not whether the patent holder should be made whole, nor whether we want to reconstruct the status quo, but simply what policies those terms effectuate. Here Sichelman's lodestar is the Supreme Court's decision in eBay Inc. v. MercExchange, L.L.C. ${ }^{21}$ Justice Thomas's opinion, as Laycock notes, probably confuses the jurisprudence of permanent and preliminary injunctions, ${ }^{22}$ but the opinion does successfully reinstate equitable considerations into the permanent injunction calculus: the comparative hardship to the parties, the adequacy or inadequacy of monetary relief, and the broader public interest. Note that here "public interest" must mean "otherwise unaccounted public interest that is neither effectuated by respecting the exclusive rights of the patent holder, nor by limiting the application of the exclusive right to the defendant." Sichelman in essence hopes to extend the public interest calculus of $e$ Bay past the injunctive context and into the liability calculus of patent damages, and seems to see the language of "making whole" as an obstacle. ${ }^{23}$

But as I have tried to show here, I am not at all certain that the terminology of "status quo ante" or "making [the patent holder] whole" always means what Professor Sichelman seems to assume that it does. I am even less certain that the terms are consistent among the subject matter of personal or property torts, contract, and patent. I take Professor Sichelman's point that courts have mechanically or reflexively excluded from the meaning of such terms certain public interests that ought to be considered in patent law, but those interests may sit very comfortably within the terminology as it should be properly understood. There is no particular need

21. 547 U.S. 388 (2006).

22. See LAYCOCK, supra note 15 , at 339-40.

23. Sichelman, supra note 1 , at 528. 
to recast the language of patent remedies, only judicial understanding of it, and the Supreme Court's eBay decision has already taken a step or two in that direction.

\section{Finding the Means}

Once we have settled on the specific meaning we want to attach to terms such as "status quo ante," or "making whole," or "rightful position," achieving the outcome tied to that meaning becomes largely a question of whether a court has the remedial tools to get there. The basic tools in the judicial kit, already discussed thus far, are monetary damages and judicial orders. These remedies map onto the categories of either liability rules (a right to be paid), or property rules (a right to exclude), under the nomenclature famously promulgated by Calabresi and Melamed. ${ }^{24}$

But the judicial toolkit of patent remedies seems notably impoverished, as Sichelman complains. ${ }^{25}$ This need not be the case, as the Supreme Court demonstrated in eBay. And as I have suggested elsewhere, even without amending the patent statute, courts sitting in equity may have either inherent authority to invoke a wider range of remedies, or may be able to find the latitude within the statute to do so. ${ }^{26}$

For example, Calabresi and Melamed recognized that symmetries between the allocation of liability entitlements suggest the possibility of bestowing a reciprocal right to be paid on the alleged infringer rather than assigning it to the entitlement holder. ${ }^{27}$ This remedial rule is familiar in the real property context as the "reverse liability rule" from the famous Spur Industries v. Del Webb ${ }^{28}$ case. In the Spur Industries case, a developer of residential homes sued to enjoin the nuisance of dust and smells from a nearby cattle feed lot, essentially asking the court for an injunction to close or move the feed lot. ${ }^{29}$ Denial or grant of the injunctive remedy would have either assigned an exclusive right to the feed lot to produce dust and odor, or assigned to the home owners an exclusive right to be free from dust and odor.

Rather than adopting one of these property rules, the court instead fashioned a different remedy. ${ }^{30}$ It held that the residential developer was entitled to an injunction, with a caveat. ${ }^{31}$ Since the developer had in some sense "come to the nuisance," putting himself and his purchasers in a position to be affected by the feed lot dust and smell, the court held that the

24. See generally Guido Calabresi \& A. Douglas Melamed, Property Rules, Liability Rules, and Inalienability: One View of the Cathedral, 85 HARV. L. REV. 1089 (1972).

25. Sichelman, supra note 1, at 528.

26. Dan L. Burk, Intellectual Property in the Cathedral, 4 ZEITSCHRIFT FÜR GEISTIGES EIGENTUM 405, 405 (2012).

27. Calabresi \& Melamed, supra note 24, at 1116-17.

28. Spur Indus., Inc., v. Del E. Webb Dev. Co., 494 P.2d 700 (Ariz. 1972).

29. Id. at 705 .

30. Id. at $707-08$.

31. Id. at 708 . 
feed lot should not bear the cost of the move. ${ }^{32}$ The developer's injunction would be contingent on a payment to the feed lot owner to offset the cost of moving his operation. ${ }^{33}$ The developer could of course also choose to forgo the injunction and avoid the payment. This effectively gave the defendant a liability right to be compensated if the plaintiff exercised his option to force relocation.

There has been little previous consideration as to how such a rule might play out in intellectual, rather than real, property. ${ }^{34}$ If we were to apply such a rule to patents, we would map the developer and the feed lot onto the patent holder and the infringer. Rather than the patent holder receiving a payment from the alleged infringer, instead the infringer would be entitled to receive the payment if the entitlement owner elected to exercise her exclusive rights. I have suggested elsewhere that this type of rule might incorporate the desirable features of a liability rule, while better harnessing the private valuation information held by parties to a lawsuit. ${ }^{35}$

For example, Sichelman discusses the Supreme Court's shift in eBay toward a type of compulsory licensing - a liability rule-rather than an automatic injunctive property rule to deal with the problem of nonpracticing entities (NPEs) or "trolls." ${ }^{36}$ The substitution of a liability rule for a property rule in this instance seems to have been fairly successful in curbing the threat of overly coercive injunctive remedies. But consider the advantages of a reverse liability rule for the NPE injunctive leverage problem. Instead of the eBay compulsory license option, imagine the application of the Spur Industries rule: a court sitting in equity might grant the patent holder its injunction contingent on paying the cost that would be incurred if the infringer adopts the next-best technological alternative. This removes the threat of shutdown from negotiations over the patented technology, as well as any advantage that might come from ambushing competitors who had unwittingly adopted a patented technology.

One might be concerned that the rule could create an incentive to infringe, as the worst that could happen would be a subsidized change to the next-best alternative technology if caught. But the answer to this objection is that, in balancing the equities of a case, the rule should only be deployed where there is evidence of innocent infringement on the one hand, or of ambush or untoward bargaining leverage on the other. These are the kinds of

32. Id.

33. Id.

34. But see Burk, supra note 26, at 409 (discussing the reverse liability rule for intellectual property); Dan L. Burk, Property Rules, Liability Rules, and Molecular Futures: Bargaining in the Shadow of the Cathedral, in GENE PATENTS AND COLLABORATIVE LiCENSING Models: PATENT PoOls, Clearinghouses, OPEn SOURCE MODEls, AND Liability Regimes 294 (Geertrui Van Overwalle ed., 2009) (same); Michael W. Carroll, One for All: The Problem of Uniformity Cost in Intellectual Property Law, 55 AM. U. L. REV. 845, 880 (2006).

35. See Burk, supra note 26, at 411.

36. Sichelman, supra note 1 , at 520-22, 562-64. 
criteria that are used in deciding whether the eBay rule should apply, and can equally well be used to help decide whether a reverse liability rule is appropriate.

This allocative rule would thus add another tool to the courts' kit of remedies, allowing judges to better tailor outcomes to specific situations. In particular, the reverse liability rule addresses the objection that liability rules are potentially inefficient because they impose a price set by an adjudicator who has imperfect valuation information. The Spur Industries rule puts the patent holder, rather than the judge, back in the driver's seat, harnessing the patent holder's private valuation. The patent holder is given the choice whether to pay the cost of the injunction or not; if the injunction is not worth the cost, he can forgo it.

The rule therefore serves to separate the trolls from the innovators: those who really need exclusivity to establish a market for the product they were producing could assert their property rights, but at a price. Trolls are allowed to voluntarily segregate themselves from non-trolls, rather than requiring a court to determine who is a NPE and who isn't. If the rule is applied in the situations of high switching costs identified by Sichelman, it similarly segregates out manufacturing entities who value exclusivity by requiring them to subsidize the defendant's switching costs.

An additional example of the usefulness of the reverse liability rule may be found in controversies over patents in the context already mentionedFRAND licensing for standard essential patents. These are paradigm cases of multiple component devices that concern Sichelman. ${ }^{37}$ Interoperation of multi-component technological systems frequently requires some type of standardization; indeed, interoperable technologies will tend toward a single standard. ${ }^{38}$ Access to, and adoption of, the standard becomes essential to effectively compete in the market, in order for products to be compatible with existing systems. ${ }^{39}$ Consequently, standards that are subject to an intellectual property right can convey enormous market power to the owner, who may be able to exclude new entrants from the market by restricting their access to the standard. ${ }^{40}$

There have been some instances where a patent holder has failed to disclose, or has allegedly willfully concealed, his proprietary interest until his technology is adopted as a standard. ${ }^{41}$ The reverse liability rule seems almost tailor-made to deal with such attempts to enforce such an undisclosed patent

37. Sichelman, supra note 1 , at 538-39, 546-50.

38. Mark A. Lemley, Antitrust and the Internet Standardization Problem, 28 ConN. L. ReV. 1041, 1042 (1996).

39. CARl Shapiro \& Hal R. VARian, Information Rules: A Strategic Guide to the NETWORK ECONOMY 245-48 (1999).

40. Mark A. Lemley \& David McGowan, Legal Implications of Network Economic Effects, 86 CALIF. L. ReV. 479, 523 (1998).

41. See, e.g., Rambus Inc. v. Infineon Techs. AG, 318 F.3d 1081 (Fed. Cir. 2003); In re Dell Computer Corp., 121 F.T.C. 616 (1996). 
against competitors who have adopted the patented standard under the impression that it would be available on FRAND terms. A court in such situations might permit the patent holder an injunction against those using the claimed technology, but only if the patent holder is willing to pay the switching costs for those who have adopted the standard and who wish to change to an alternative. This would likely deter most patent holders from asserting their patents once the patented technology was adopted as a standard. Those who truly wished to assert their exclusivity could do so, but at a cost. The cost might be considered an equitable or restitutionary penalty for not dealing openly in the first place. ${ }^{42}$

\section{Means to an End}

Some time ago, scholars recognized that the reciprocal liability rules described by Calabresi and Melamed closely resemble the financial instruments known as "call" options, which are contracts that allow a party to buy a commodity at a predetermined price, at that party's option. ${ }^{43}$ For example, both the liability rules discussed so far-patent damages and patent injunctions subject to a reverse payment - take the form of a call option, allowing one of the parties to an infringement action to use the claimed invention at a price set by the court-essentially a forced purchase of the patent asset. ${ }^{44}$

If liability rules resemble call options, then this raises the possibility of introducing another set of complementary and reciprocal allocative rules that resemble "put" options. ${ }^{45}$ These financial instruments are contracts that allow one of the parties to sell a commodity at a predetermined price, at that party's option. ${ }^{46}$ An analogous juridical remedy, inverse to the liability rules discussed above that entitle a party to pay when they choose to infringe a right, would give one or the other party the option of being paid to relinquish the right to a prospective entitlement. Put rules may be thought of as comprising a two-step decisional process in which the infringer decides whether to take the asset, and the entitlement holder then decides whether to assert exclusivity or opt for a damages payment. ${ }^{47}$

In the context of real property, a number of scholars have pointed out that a put option operates as a type of easement, which has its own value

42. See Taylor v. Meirick, 712 F.2d 1112, 1120 (7th Cir. 1983) (opinion by Judge Posner reasoning that restitution entails penalties for bypassing market negotiations).

43. See Ian Ayres, Protecting Property With Puts, 32 VAL. U. L. REV. 793, 795-96 (1998).

44. Cf. id. at 796 .

45. Id.; Ian Ayres \& J. M. Balkin, Legal Entitlements as Auctions: Property Rules, Liability Rules, and Beyond, 106 YALE L.J. 703, 731 (1996).

46. See Ayres, supra note 43, at 796 (explaining the difference between call options and put options).

47. Id. at 800,823 . 
independent of that of the property to which it is attached. ${ }^{48}$ Property rights subject to such an easement may be worth more than the property right alone, and a property owner who is compensated for the value of both entitlements may receive more than the value of the underlying property. Sichelman notes that some situations may arise where the traditional measure of damages will undercompensate the patent holder relative to the optimal incentive; he suggests that some type of additional, possibly publicly funded, compensation will be necessary in such cases. ${ }^{49}$ One can imagine such a system built around the value added of a put-type rule, indeed I have suggested such a model in some previous work. ${ }^{50}$

This type of "put" rule is relatively rare in Anglo-American jurisprudence, including in the law of intellectual property, although a few examples exist. ${ }^{51}$ But the rudiments of such a system can be seen in the current discussion over "reverse payments" for pharmaceutical patent challengers under the Hatch-Waxman Act. ${ }^{52}$ The Hatch-Waxman Act is a complicated series of legislative compromises between original pharmaceutical developers and generic manufacturers. There is a social need for patents to prompt investments into original research for new pharmaceuticals, but there is also a social need for early, low-cost competition in the market by generic follow-on manufacturers. One impediment to competition is the threat of unnecessary, obstructive patents. Removing such patents through litigation is a high-cost, high-risk undertaking.

As a reward for undertaking the expense of challenging defective, obstructive patents, Congress provided that a follow-on manufacturer who successfully challenges a patent is entitled to a 180-day period of market exclusivity. ${ }^{53}$ In such instances, the first follow-on manufacturer who brings suit against the patent holds what is effectively an option on a 180-day injunctive property right, which could of course be waived in return for a payment. Not surprisingly, patent holders have offered such payments with some frequency, essentially offering to split the value of the statutory right. ${ }^{54}$

Although this could be conceptualized as a purchase by the patent owner of the challenger's option to proceed in securing market exclusivityin other words, purchasing the easement on the patent-the reciprocal entitlement structure pointed out above means that the reverse payment is

48. Id. at 799; Carol M. Rose, The Shadow of The Cathedral, 106 YALE L.J. 2175, 2178-79 (1997).

49. Sichelman, supra note 1, at 558-60.

50. See Burk, supra note 26 , at $416-17$.

51. See Ayres, supra note 43 , at $814-15$.

52. Drug Price Competition and Patent Term Restoration (Hatch-Waxman) Act of 1984, Pub. L. No. 98-417, 98 Stat. 1585 (1984) (codified as amended in scattered sections of 15 U.S.C., 21 U.S.C., 28 U.S.C., and 35 U.S.C.).

53. 21 U.S.C. $\$ 355(\mathrm{j})(5)(B)(\mathrm{iv})$ (2012).

54. C. Scott Hemphill, Paying for Delay: Pharmaceutical Patent Settlement as a Regulatory Design Problem, 81 N.Y.U. L. REV. 1553, 1560-61 (2006). 
also essentially a repurchase by the patent owner of its own patent exclusivity. This is a patent subject to an easement, with the option structure described above. In the first phase, the generic challenger decides whether to provoke a lawsuit via infringement. The challenger must then decide whether to accept a payment or further invest in litigation to secure the 180day exclusion.

The payment offered to the challenger in such instances has been largely the subject of ex post negotiation rather than a predetermined exercise price-not quite the paradigm of the option contract that was described above. However, under the recent decision of the Supreme Court in FTC v. Actavis, Inc., ${ }^{55}$ such payments are subject to a judicial rule-of-reason analysis. ${ }^{56}$ Thus, the price for which a patent challenger can waive exclusivity is now limited, if not set, at some level by judicial oversight, similar to the familiar judicial determination of damages for liability "call" rules. And, significantly for Professor Sichelman's agenda, the Court's Actavis opinion suggests that this judicial calculus includes elements of the public interest, including both the interest in promoting innovation through exclusivity and the interest in promoting efficient competition.

\section{Conclusion}

Professor Sichelman is surely right that patent remedies need to be reimagined, although as I have indicated here, I am not certain that I endorse, or even entirely understand, his premise that current patent remedies are necessarily founded on the correction of private wrongs. But I am relatively certain that the premise neither drives his analysis nor is necessary to his prescriptions. To the extent that he calls for the public interest in innovation to be more fully incorporated into the remedial calculus, this requires perhaps some reorientation of judicial attitudes, but not necessarily a reorientation of remedial patent doctrines. And to the extent that he recommends a broader array of remedial outcomes, many of the needed tools are already available. They need only to be recognized and employed. 